\title{
CRIMINAL ASPECT OF INJURIES IN SPORTS
}

\author{
${ }^{1}$ Sanja Mandarić, ${ }^{2}$ Veljko Delibašić \\ ${ }^{1}$ University of Belgrade, Faculty of Sport and Physical Education, Serbia \\ ${ }^{2}$ Lawyer form Belgrade, Serbia
}

\begin{abstract}
In this paper the concept of sports ethics is defined and attention is directed to kinds of behavior which are not considered as fair play, the general conception of criminal offence as well as the elements of general idea of criminal act, unlawfulness and guilt with special attention paid to the basis on which unlawfulness and delict, and with them, the criminal offence itself are excluded. Consent of the injured party as basis for excluding unlawfulness has been carefully considered, with emphasis on the fact that with accepting to participate is a certain sport an athlete does not consent to be hurt outside the frame which rules of a particular sport imply. The attitude is accepted that with his consent an athlete consented to the possibility for his integrity be endangered, which still does not mean that he consented to be injured indeed, i.e. a difference is recognized between the consequence of endangering and the consequence of injuring protected assets. After that, rules which are applied in certain sports are explained and connected with the acceptance of the injured party, and the stand is taken that acceptance of the injured party excludes existence of criminal deed only in a situation when an injury occurred within the rules of a particular sport. If the injury occurred by breaking the rules of the sport, it would be considered as a criminal act. In conclusion, the stand is taken that it is necessary to fight against all harmful occurrences in sports, including the injuries which occurred due to severe violation of rules which should be applied in a particular sport. It is concluded that consent of the injured party must not be an excuse for not applying criminal justice, if the injury occurred by violation of the rules of a particular sport.
\end{abstract}

Key words: ETHICS / FAIR PLAY / CRIMINAL OFFENCE / CONSENT OF THE INJURED / EXCLUDING UNLEWFUNNESS / BODILY INJURY

\section{INTRODUCTION}

Sport as a complex, multidimensional phenomenon is a part of the overall culture of a nation, and apart from competitions it includes social, psychological, pedagogical, medical, economic, scientific, cultural, legal, political and other assets (Stefanović, 2011). Apart from this, sport can be viewed from both positive and negative aspects. Positive aspect is based on the attitude that sport is, amongst other things, the most valuable cultural phenomenon of contemporary society, a mechanism of personal and social affirmation, group identification, togetherness, which glorifies the culture of body, an esthetic issue, but also manifests the life-style of the young. On the other hand, negative attitude is based on the stand that sport is a high risk area, expressing the instinct of rivalry, deformed form of playing, area susceptible to violence and manipulating masses (Kovačević, 2011).
According to all this, it could be said that, apart from the usefulness of sport which is indisputable, first of all for those who participate in it, athletes are the very ones who are prone to harmful phenomena which are part of it, injuries included. Injuries occur for various reasons, both in sports whose rules do not allow for hurting your opponent such as football, basketball volleyball, wrestling, judo, athletics etc, as well as in those whose rules allow hurting your opponent in order to win a competition, for example boxing, kick boxing, MMA etc.

Regardless of the sports discipline, in contemporary society the cause for injuries can be connected with aggressive and violent behavior of athletes during competitions. The fact is that in contemporary world, desire for success is firmly connected with gaining profit, and athletic events turn into aggressive fights for result and prestige. In professional sport, in which winning is an imperative, competitors often treat others merely as objects and obstacles they 
need to conquer (Hosta, 2008). This is why during competitions certain athletes demonstrate uncontrolled behavior which is characterized by roughness, aggressiveness, and absence of sports ethics and fair play, which is not in accordance with the rules. This kind of behavior of athletes during competitions on sports courts can result in injuring the opponent, but also in far reaching sociological consequences on the audience and young people who look for role models among athletic stars (Božović, 2007).

General obligation of applying criminal law in the field of sport, even when we talk about bodily injuries which occurred during a competition, cannot be disputed. Their criminal-legal evaluation and qualification impose many legal questions, though. There are many approaches to solving this problem (consent of the injured party, social acceptance, allowed risk, exclusion of unlawfulness in sports manifestations, legal vacuum), but due to a variety of situations in sports in which injuries can occur, it is necessary to take into consideration all of the above mentioned in order to get the whole picture. The order is as follows: during a game which is played according to rules, not punishing can be justified as socially acceptable, minor violation of rules is covered by allowed risk, major violation requires the consent of the injured party, and in intentional injuries the borderline between allowed and unallowed injury is clearly overstepped and calls for criminal sanctions (Marković, 2013).

\section{ETHICS IN SPORTS}

Sport today is characterized by insufficient respect of general rules of behavior, so during athletic competitions one can notice that rules for sports and sports competitions are not obeyed. For that reason the questions of ethics and the problem of morality in sports is one of the central questions on the scale of social items and values, i.e. on the scale of functioning and building good social relations.

When terms such as ethics and sports, i.e. ethics in sport are mentioned, one usually thinks of the negative aspects of sports. The fact that we are witnesses of numerous unethical elements connected with sport, such as doping, bribe and corruption, "fixed" matches, aggressive and violent behavior, as well as mutual insulting of athletes and coaches on various grounds (Brkljačić, 2007; Mandarić, \& Delibašić, 2014; Delibašić, \& Mandarić, 2015).
Ethics (Greek èmxoc - custom) together with esthetics belongs to the category of philosophy, originating from practical philosophy which is called axiology or the theory of values. As part of philosophy, ethics deals with studying and evaluating morality, i.e. notions of good and right. Each ethical theory contains at least two components, the one which determines what is good or valuable, and the other which determines what is right. In accordance with this, it could be said that morality represents a type of social consciousness, which in practice implies something that is good from the aspect of interhuman relations, as well as relationship of an individual towards the society as a whole. In connection with that, moral values represent a group of norms and rules of human behavior, especially good ones.

As society moves, develops, structures itself, moral values, norms and ethical notions of the mind develop and grow with it. Old, previous norms of behavior change into new views and opinions, new systems of values, i.e. new moral values are created instead of the old ones. In accordance with this, it could be said that morality is not timeless and unchangeable, and there is no one general morality which has and had been accepted in all societies and periods of time (Stefanović, 2011).

When we talk about the question of ethics in sports, it could be said that it represents the implementation of generally known moral values for the same situations in sports and sport as a whole (Ceraj, 2005), i.e. behavior of athletes according to various international and national codes of behavior which are morally relevant. In other words, sports morality represents a set of rules for athletes' behavior which he should show in all segments of sport. However, it is a fact that athletic competition is an area in which, more than anywhere else, moral values in interhuman relationships can be tested. Since sport is an area of personal and group victories and defeats, moral initiatives as well as moral failures are most noticeable in it (Stefanović, 2011).

Basis of moral behavior of an athlete can be found in ancient Greek ethic norms, according to which, based on Plato's ideas, basic values which characterize a top athlete were wisdom, courage, moderation and justness (Čeh, 2013). In ancient Greece there was an ethic code of behavior, which participants in pankration (combination of wrestling and boxing) obeyed. Pankarationists had to preserve their opponent's life, show mercy on anything living, be dedicated, just, true and righteous towards everyone and hospitable 
towards strangers. Each pankrationist had to be noble, righteous, modest and dignified $(\Sigma \alpha \beta \beta i \delta \eta \varsigma, 2001)$.

It can be said that athletic morality, i.e. in a wider sense sports ethics, is a group of norms or rules which regulate relationships and determine the behavior of people participating in it, prescribing moral duties of the members of athletic organizations towards society, sport and relations of individuals within it (Stefanović, 2011).

Morality in sports is presented thorough fair play, under which honorable competition or knighthood is understood. Fair play is a worldly renown concept, which developed during the nineteenth century, together with the development of modern sport in Great Britain, and it mostly reflects the English athletic way of life, as well as their perception of competition in sports (Renson, 2009). Basic rules of fair play consist of respecting the rules of competition, one's opponents and judges. In accordance with this, athletes should respect their opponents, and should not use dishonest means. When they are winning, they should never insult their opponent, and when they are losing they should know how to keep their dignity, and honor their opponent for his victory.

Principles of fair play of the founder of modern Olympic Games, baron Pierre de Coubertin, have a special significance in the context of ethics in sports, and they imply development of correct, friendly relations amongst athletic opponents, respecting rules and judges' decisions, development of activism in order to dignify athletic combat during competition, harmonize personal needs with needs and interests of the team, club or national selection, development of anticolonial, anti racist and anti nationalist attitudes in various athletic competitions (Kozarčanin, 2008).

In this day and age, we can witness athletes behaving not in accordance with the principles of ethics and fair play in sports. The behavior of a French representative Zinedine Yazid Zidane, ten minutes before the end of the final match at the World Championship held in Germany in 2006, astonished the audience and cast a shadow on the final match. Zidan was disqualified in the second half term of the game because he had hit the Italian representative Marco Materazzi with his head. After the incident, the recording of the game showed that Zidan and Materazzi talked for a while, after an unsuccessful attack of the French team, after which Zidan started to walk away. However, Materazzi kept talking after which Zidan returned and hit him with his head. The Discipline Committee of World Football Federation fined
Materazzi with 5000 Swiss francs, since he had admitted having insulted Zidan, while Zidan's athletic career was ended due to his unsportsmanlike behavior. However, his sports biography indicated that he was frequently sanctioned during games for rough and violent behavior, crude violations of rules and hitting his opponents. These and similar types of disregarding ethical, fair play, lead to the behavior which loses positive characteristics and indirectly contribute to the decline of sport.

\section{GENERAL NOTION OF A CRIMINAL OFFENCE}

Criminal Code proscribes that a criminal offence is a deed which is legally anticipated as one, which is unlawful and committed (Article 14, Paragraph 1 CC). This means that general concept of a criminal offence consists of four constitutive elements: deed, anticipation by law, unlawfulness and guilt. These four elements are at the same time four degrees which are characterized by progression during their establishment in a specific case, which should contribute to better and more correct application of criminal law. The order of separate elements is not stated arbitrarily in the Criminal Code, and it cannot be changed without causing unacceptable theoretical and practical consequences. Namely, degree in establishing existence of the four mentioned elements is very important. During solving a concrete case and application of criminal law one always begins with the deed (offence), and ends with delict. In accordance, four obligatory elements in the concept of criminal offence simultaneously represent four degrees, or levels through which one must go in order to establish that a criminal offence has been committed (Stojanović, 2012).

First it is established whether a deed fulfills the conditions to be qualified as a criminal offence. On that, first level, as a rule, only a small number of deeds will not fulfill the minimal conditions in order to be qualified as a criminal offence. However, on the next level or degree, when establishing whether significant characteristics of the legal description of a criminal offence were met, there is a considerable narrowing of the circle of deeds in which all legal conditions for establishing a certain criminal offence were met. Anticipation by law is an element in general concept of criminal offences in which a considerable number of human acts which could potentially be qualified as 
offences are reduced to a relatively limited group of acts. Meeting all characteristics anticipated in a legal description of a certain criminal deed still does not imply the existence of a criminal offence, not even of criminal wrong. We still cannot definitely indicate a criminal wrong in such behavior, i.e. that it is unlawful in the criminally offensive sense, although there may not be only strong indications, but it could be said that its unlawfulness was constituted. Establishing unlawfulness occurs on the next level. It is, in fact established whether unlawfulness of a behavior which fulfills the legal characteristics of a criminal offense was excluded (for example, whether depriving someone of his life was committed in self defense etc). Only if there is no basis for excluding unlawfulness, it could be stated that a criminal wrong was committed, that there is a criminal offence in an incomplete, objective sense. Finally, it is necessary to establish the guilt of the offender in order to establish a criminal offence. That is the last level on which a decision and final judgment are made whether a criminal offence has been committed. First three (objective) elements can exist without the fourth, i.e. guilt, but never vice versa: there is no guilt if objective elements have not been met (Stojanović, 2012).

\section{UNLAWFULNESS AND GUILT}

Determining human behavior as a criminal offence in Criminal Code necessarily implies its unlawfulness. If a behavior contains all elements stated in the legal description of the essence of a criminal offence, that kind of behavior is unlawful in itself. Unlawfulness in criminal justice does not exist if a deed is not stated in the Criminal Code as a criminal offence. In exceptional cases, unlawfulness can be excluded, and due to this, although a deed has been stated in the Criminal Code as a criminal offence, it would no longer be regarded as one. The reason for introducing unlawfulness as a constitutive element in the general notion of a criminal offence is actually the basis of excluding unlawfulness, and the element of unlawful in that sense could be determined in the negative sense, as absence of bases which would exclude unlawfulness (Stojanović, 2015).

Guilt exists if the offender was sane at the time of the deed and acted with intent, and was aware of the fact that his act was forbidden or was bound to be or could have been aware (Article 22, Paragraph 1 CC).
Criminal act was also committed with guilt if the offender acted from negligence if it is specified in the Criminal Code (Article 22, Paragraph 2 CC).

Intent is a higher degree of guilt and it always requires existence of a criminal act. Exceptionally, in some criminal offences, negligence is stated as a milder degree of guilt, i.e. lighter form of certain criminal offence is stated considering the degree of guilt. From the legal definition of intent (dolus), two kinds of intent are drawn: direct and oblique (Paragraph 25, CC). According to this definition, a criminal offence was committed with direct intent if the offender was aware of his deed and wanted to commit it, and oblique intent exists if the offender was aware that he could commit the deed and consented to it.

Negligence (culpa) is a milder form, i.e. lower degree of guilt in comparison with intent. In cases when Criminal Code anticipates an unintentional form of an offence, the recommended punishment is always milder in comparison with intent. Law recognizes two types of negligence: advertent and inadvertent (Article 26 CC). Advertent negligence (luxuria) exists when the offender was aware that his action could lead to the deed, but believed that it would not be the case or that he would be able to prevent it. In advertent negligence law anticipates two situations where, in the first one, the offender believes in his abilities which are overestimated, while in the second he misjudges the objective situation. In both cases, unlike indirect intent, he does not consent to the consequence. Inadvertent negligence (negligentia) exists when the offender was not aware that his acting could lead to the deed, although under the circumstances it had occurred and due to his personal characteristics, he was bound to be aware and could have been aware.

It is especially important which form of intent or negligence it was, since the answers to a number of questions depend on it, starting with whether it was a criminal offence at all, and which one, up to delivering the appropriate offensive sanctions. While the problems of determining between direct and indirect intent are less prominent and as a rule are not of considerable importance, one of the most important problems about intent, and guilt as a whole, is determining between indirect intent and advertent negligence. Namely, the element of awareness is the same, and there is a difference concerning the element of will: in indirect intent the offender consents to commit a criminal deed, while in advertent negligence he does not want the consequence, i.e. does not consent 
to commit a criminal deed. This means that the legislator, among several theories which are trying to deal with this problem, chose the theory of consent. Consent should be estimated by regarding the consequence of the criminal deed first, since, as a rule, in disputable cases, it is about consequential criminal offences. Namely, inadvertent criminal offences are almost always consequential criminal offences (Stojanović, 2015).

\section{BASES FOR RULING OUT UNLAWFULNESS AND GUILT}

There is no criminal offence if unlawfulness or delict are excluded, although there are all characteristics of a criminal deed described in the Criminal Code (Article 14, paragraph 2 CC). There are three basic exclusions of unlawfulness, and with them exclusions of criminal offence described in Criminal Code, and they are the following: a minor deed, self-defense and extreme necessity. Therefore, a deed is not a criminal offence if, although it might contain elements of criminal offence, it is a minor deed (Article 18, Paragraph $1 \mathrm{CC}$ ) and it is of minor importance if the degree of guilt of the committer is low, if harmful consequences do not exist or are insignificant, or if the general aim of sanctions does not require for delivering a criminal sanction (Article 18, Paragraph 2 CC). These rules can be applied to criminal deeds for which prison sentence up to five years or a fine are proscribed (Article 17, Paragraph 3, CC). Also a deed is not a criminal offence if it was committed in self defense (Article 19, Paragraph 1, CC), and self defense is concluded if it was necessary for the committer to defend his property or property belonging to somebody else from an unlawful simultaneous attack (Article 19, Paragraph 1, CC). Apart from that, a deed committed in extreme necessity is also not a criminal offence (Article 20, Paragraph 1, CC), and extreme necessity exists when a deed was committed while the committer was trying to remove from his or other's property a simultaneous unlawful danger which could not have been removed in another way, and the harm committed was not greater than the threatening harm (Article 20, Paragraph 2, CC).

Apart from these three basic exclusions of unlawfulness anticipated by the Criminal Code, there is a number of other basis for excluding unlawfulness anticipated by other regulations, or result from the at- titudes of doctrine or courtroom practice. These are: performing one's duty, order of the superior, consent of the injured, allowed risk (this grounds is disputable), right to disciplinary punishment of minor children or performing medical interventions.

Basis for excluding guilt and with it, criminal deed are a compulsive force (Article 21, CC), insanity (Article 23, CC), unrecoverable real error (Article 28, CC), unrecoverable legal error (Article 29, CC). In connection with that, the committer who could not understand the meaning of his deed or could not manage his actions due to a mental illness, temporary mental disorder or underdeveloped mental state or other more developed kind of mental derangement, is considered as insane. Real error is unrecoverable if the committer was not bound to and could not have avoided the error regarding a real circumstance which has the characteristics of a criminal offence or regarding some real circumstance which would have, had it really existed, made the deed lawful. Legal error is unrecoverable if the committer was not bound to know or could not have known that his deed was prohibited.

\section{CONSENT OF THE INJURED PARTY AS BASIS FOR EXCLUDING UNLAWFULNESS IN ATHLETIC COMPETITIONS}

The law on sports defines sport as an activity of special significance for the Republic of Serbia, which is part of physical culture and includes all forms of organized and unorganized performances of athletic activities and actions by physical and legal entities in the system of sport, in order to satisfy the needs of people for creativity, affirmation, physical exercise and competition with others. Athletic activities are all forms of physical and intellectual activities which, through unorganized or organized participation aim at expressing or improving physical readiness or spiritual welfare, creating social relations or achieving results at all levels of competitions, while athletic actions are those that provide conditions for performing athletic activities, i.e. conducting athletic events including: organizing participation in and management of athletic competitions including international competitions, training for practicing sports activities, planning and carrying out sports activities; refereeing; organizing athletic preparations and 
events; safeguarding and managing athletic equipment and objects; professional education, practice, improvement, providing information in the field of sport; counseling and professional services in sport; sports mediation, organizing business organizations in the field of sport.

People who participate in sport, regardless whether it is a professional, amateur or recreation arrangement, can commit deeds which can be understood as criminal offences against life and body during athletic activities and performances, and then one can ask whether something was a criminal offence at all, i.e. if it was not a criminal offence, what is the basis for exclusion of a criminal deed in that particular situation. The answer to this question will depend on each particular case, and, most of all, whether the deed happened within the rules of a particular sport, whether there is basis for exclusion of unlawfulness or delict, i.e. a criminal offence. The most frequent criminal offences in these cases are: minor injury (Article 122 CC), major bodily injury (Article 121,CC), murder (Article 113, CC), negligent deprivation of life (Article $118 \mathrm{CC}$ ) and participation in a fight (Article 123).

Consent of the injured party, as a general institution which excludes unlawfulness, should be differentiated from the cases when the elements for criminal offence simply have not been fulfilled, since consent of persons to which certain acts were committed exclude force as an important element of these criminal offences (for example, consent is not acceptable in criminal deeds of robbery, rape, extortion etc), or due to consent the deed was not committed in an unauthorized way, which is a necessary element in some criminal offences (for example, criminal offence of violation of secrecy of letters or other packages, or unauthorized disclosing of confidential information by lawyers or doctors). Unlike the stated situations where there is no anticipation by law as an element of the general notion of a criminal offence, here it is about the fact whether the consent of the injured party should be given the character to be the basic condition for excluding unlawfulness. It is certain that in some criminal offences, i.e. protecting a certain asset for the protection of which society as a whole is interested, the right to decide whether a criminal deed would be excluded cannot be given to an individual. That is the central issue of consent of an injured party as basis for excluding unlawfulness: where to draw the line between criminal offences for which society is absolutely interested, and those where it would be possible to allow the passive subject to exclude unlawfulness by his consent. In some personal assets, which are ranked very high, there is a significant social interest, so individuals cannot be allowed to decide on them although they might be the direct holders of those assets (for example, right to life). Indirectly, legislator accepts the importance of consent of the injured party by allowing civil lawsuits for certain criminal deeds, i.e. it depends on the will of the injured party whether criminal law would be applied (Stojanovic, 2015). For example, for a common, minor bodily injury prosecution is conducted as a civil law suit according to Article 122, Paragraph 1 of the Criminal Code.

Considerable possibility and probability of inflicting injuries during sports activities indicate the necessity of changing the institution of consent of the injured party when establishing the responsibility for the inflicted injuries (Kolarić, 2002). That way the consent of the injured party is significant especially in some sports in which participants accept the possibility of possible injuries. Criminal offence will be ruled out if the injury was inflicted within the rules of an athletic competition. Two situations are possible here: either the injury itself was allowed (for example in boxing), or the injury was usual and penalized according to the rules of the game (foul in football). On the contrary, if it was intended or if it was not inflicted within the rules of the sport, but for other reasons and motives, it would be a criminal offence (Stojanovic, 2015).

Regarding this, a difference should be made between behaviors which are reasonably anticipated when participating in sport and behaviors which are not anticipated. With participating in sport, a person consents to the acts which are reasonably anticipated in a particular sport (Harary, 2002). In other words, first it should be noted that the consent to endangerment does not imply consent to the occurring consequence, but more consent to a dangerous act. From the facts that a person consented to be exposed to a certain risk, a long-term conclusion cannot be drawn that he consented to be injured. Therefore the consent to the stadium of endangering does not automatically imply consent to the stadium of injury, so a similar consent can rule out only the unlawfulness of the delict of endangerment. Therefore in the area of sports, only a consent to involuntary endangerment of bodily integrity is considered as acceptable (Vuković, 2013).

Therefore, an attitude can be accepted that consent should be allowed only in limited circumstances. 
Namely, a player can give implied consent to certain predictable forms of athletic contact which could have been considered as criminal attack had they occurred outside an athletic court. However, this does not mean that the player consents to voluntary infliction of injuries which are outside the frame of anticipation within a competitive game, i.e. no contact which surpasses the limitations of the game can be considered as consented to (Harary, 2002). With it, responsibility is not established subjectively, meaning that the victim had been informed about it and therefore consented, but is established according to objective standards and in accordance with the rules of a particular sport. This means that the participants consented to what was implied in the usual course of the game, and consent results from the evaluation of circumstances under which the deed occurred (Livings, 2007).

In the end, it should be said that serious endangerment of an athlete's health, which in criminal-legal sense could represent a major bodily injury, and there are cases in which death had occurred, could result from using doping agents (Mandarić, \& Delibasić, 2014; Delibašić, \& Mandarić, 2014). In case when the essence of a criminal deed was achieved by using a doping agent from Article 38 of the Law on Prevention of Doping in sport, the consent of an athlete is irrelevant for the existence of a criminal deed. In that case, consent of an athlete could be considered as an extenuating circumstance when deciding on the punishment.

\section{RULES OF CERTAIN SPORTS AND THE CONSENT OF THE INJURED PARTY}

There are divisions of sports according to various criteria, and one of them is the division into contact and non contact sports. Contact sports are those in which the opponents come into physical contact within rules of the game (handball, basketball, water polo, football, rugby, judo, wrestling, boxing etc) while in non contact sports there is no physical contact between competitors (table tennis, tennis, badminton, volleyball, athletics, bowling, cycling, car racing etc). When we talk about the possibilities for injury, the basic division would be into sports in which injuries are allowed and those in which they are not. One should bear in mind that even in sports in which injuries are allowed, not all kinds of injuries are allowed, i.e. not all ways of hurting other players are permitted.

It is known that during the period of ancient Greece, it was allowed to hurt one's opponent during athletic contests in chariot racing and Martial arts in which violence, i.e. hurting one's opponent, was almost glorified. During that period, there were very few or no limitations in Martial arts. So in boxing, it was allowed to hit the opponent directly in the face, genitals, body, downwards. Eye-poking and biting were the only things which were not allowed. In wrestling, all grips were allowed, even breaking the opponent's fingers (Pausania, 1994).

Minor bodily injuries can occur in all contact sports, and they include: scratches, bruises, abrasions and minor injuries of muscles and bones. As a rule, in those cases they will not be considered as criminal deeds, unless the minor bodily injury was inflicted intentionally, using behavior which is not allowed in the rules of a sport in question. For example, in football it is not allowed to bite your opponents, which is something Luis Suárez did several times, and with it he committed a criminal act or inflicting a minor bodily injury. Here one should bear in mind that for minor bodily injuries a civil lawsuit is proscribed, and this further means that whether the offender will be prosecuted and convicted for a minor bodily injury depends on the will of the injured party.

The situation in boxing is identical. There it is allowed to inflict injuries to the opponent within the rules of boxing, i.e. it is allowed to hurt the opponent by hitting him with the fist which is inside a boxing glove, but it is not allowed to kick him or bite him, which Michael - Mike Tyson did when fighting for the World Champion title, when he bit off a piece of the ear of Evander Holyfield, during a match in 1998 in Las Vegas. That time Mike Tyson was disqualified, and in his autobiography he wrote that he was aware of what he did, but that during the fight he had not been thinking about boxing, and that his move was due to the rage he felt since he had received multiple hits on the head from Holyfield (Tyson, \& Sloman, 2013). To this example, consent of the injured party cannot be applied as basis for exclusion of unlawfulness, i.e. criminal deed, since Holyfield, who consented to be hurt according to the rules of boxing, certainly had not consented to be bitten, i.e. for the opponent to bite his ear off. This further means that criminal offence was committed and that there was room for full application of criminal law. 
In order to apply regularly the institution of acceptance of the injured party, it is especially important to answer whether a certain behavior is allowed of prohibited within the frame of a particular sport. The answer to the question whether something was a criminal deed or not i.e. whether the existence of a sanction for certain behavior within a particular sport includes or excludes the existence of a criminal deed may depend on it. For example, fouling the opponent in football is not allowed, i.e. it is prohibited, so in the case of breaching the prohibition a corresponding sanction may be decided on, or penalized as a foul for which a yellow or a red card might be shown. All this represents the sanction within the game. Therefore an attitude could be argued that the behavior which is forbidden by rules of the game, even those behaviors for which the rules do not proscribe a particular sports sanction, do not exclude the existence of a criminal deed. In other words, if a minor or serious injury occurs as a result of a foul in football, it could be argued that it was a criminal deed, since the very game does not allow that kind of behavior.

There is a similar situation in other sports, for example, ice hockey, where it is allowed to hit the player who is holding the puck, or held it just before that, with one's shoulder or side, but it is not allowed to bite any part of the opponent's body, hit the opponent with the protruding part of the stick, attack him with unnecessary force, run into or jump onto the opponent, or attack him from the back. It is also not allowed to hit him with any part of the body or equipment, in the head or neck, or stick the head of the opponent into the protective glass or fence, use one's elbow or knee to foul the opponent, swing the skate towards the opponent, and it is especially forbidden to hit him with the stick, and also no contact with the referee is permitted (Book of rules 2014-2018).

Still, it should be mentioned that fouls in football or ice hockey can be subsumed under a wider set of rules of the game, i.e. that fouling one's opponent in football, hockey and other sports is allowed and will be sanctioned within the game itself. Only if a player exceeds the rules of the game, for example, a sudden violent attack on an opponent player could not have been allowed by rules of football in any way. Furthermore, behaviors which are indisputably and strongly forbidden like hitting the opponent without the ball, which are sanctioned by the referee, are criminal deeds. In connection with this it could be argued that there is a consent of the injured party to be fouled within a wider understanding of the rules of the game, which could be grounds for exclusion of a criminal deed. However, athletes do not consent to be hurt by actions which drastically exceed the framework of even wider interpretation of the rules of the game, and therefore if an injury which has elements of a criminal deed occurs, it would be considered as such. In connection, it should be pointed out that, in the end, the answer to the question whether something was a criminal deed or not should be searched in the field of awareness, i.e. intent and negligence of the offender, together with the institution of the consent of the injured party.

\section{CONCLUSION}

Sport is a beneficial social activity with many positive effects, first of all for those who participate in it. Apart from the indisputable benefits that athletes have due to participating in sports, they are prone to some harmful occurrences which come with it, including injuries, which can occur within the rules of a particular sport, but also due to breaking those rules. In a situation when an injury occurs, the question is whether it was a criminal offence, i.e. if it was decided that it was not a criminal deed, what were the grounds for ruling out a criminal deed. As a rule, then it comes to the institution of the consent of the injured party, which excludes unlawfulness and with it the criminal deed.

Consent of the injured party is applied in cases when the injury occurred within the rules of the specific sport, but this institution cannot be applied if it occurred due to an act which exceeded the limitations of rules of a particular sport (for example, a kick in boxing). Then criminal law has to be applied, since it is necessary to fight against harmful occurrences in sports including injuries, especially those which occur due to a severe violation of rules of a particular sport. In connection, the consent of the injured party should not be an excuse for not applying criminal law, when the injury occurred by intended violation of rules of a particular sport.

Namely, this institution can be applied only when the offender negligently injured the opponent within the rules of a particular sport which includes a wider concept i.e. the concept which also includes the "allowed" offences in a particular sport (foul in football). Also, the consent of the injured party is applied for 
injuries inflicted in those sports the rules of which allow hurting one's opponent within the competition in order to win (boxing, kick boxing, MMA and others), but only for injuries which occurred in accordance with the rules of that sport, since the opponent consented only to those injuries, and not to the injuries occurring as a result of violation of the rules (for example, injuring the opponent who has given up, after the referee stopped the fight, by applying a forbidden hit/kick etc).

In criminal aspect of injuries in sports, the question of awareness is also important, i.e. intent or negligence of the offender, and whether the deed was a

\section{REFERENCES}

1. Božović, R. (2007). Agresija i nasilje u sportu [Agrresion in Sport. In Serbian]. Sociološka luča, $I(2), 100-112$.

2. Brkljačić, M. (2007). Etika i sportu [Ethics and Sport. In Serbian]. Medicina, 43, 230-233.

3. Vuković, I. (2013). Pristanak povređenog kao osnov isključenja protivpravnosti [Consent of the injured as a basis for excluding unlawfulness. In Serbian]. In Đ. Ignjatović (ur.), Kaznena reakcija u Srbiji - III deo (pp. 175-186). Beograd: Pravni fakultet.

4. Delibašić, V., \& Mandarić, S. (2014). Krivičnopravno suzbijanje dopinga u sportu [Criminally combating doping in sport. In Serbian]. In Proceedings of conference Charges and other instruments of state criminal justice responses to crime (pp. 575-590). Zlatibor: LIV Regular Annual Meeting of the Serbian Association for Criminal Law Theory and Practice.

5. Delibašić, V., \& Mandarić, S. (2015). Nasilničko ponašanje na sportskoj priredbi ili javnom skupu [Violent behavior at sports events or public assembly. In Serbian]. Kultura polisa, 12, 79-92.

6. Kovačević, B. (2011). Društvo, nasilje i sport [Society, violence and sport. In Serbian]. Violence and sport - Proceedings of the international conference on the theme "Youth and violence in sport in the Republic Srpska - Bosnia and Herzegovina and the provision of sporting events (pp. 38-46). Banja Luka: European Defendology center for scientific, political, economic, social, security, sociological and criminological research. criminal offence, which one and whether the institution of consent of the injured party will be applied would depend on it. For example, whether it was a major bodily injury from Article 121, Paragraph 1, 2 or 3 CC (intended major bodily injury) or from Article 121, Paragraph 4 CC (unintended major bodily injury) would depend on it.

In any case, the institution of the injured party is unacceptable in a situation when the injury occurred by severe violation of the rules of a particular sport, and then it would be a criminal offence, i.e. it would be necessary to apply criminal law in the specific occasion.

7. Kozarčanin, A. (2008). Etika u sportu [Ethics in Sport. In Bosnian]. Sport Science, 1(1), 54-56.

8. Kolarić, D. (2002). Krivično delo teške telesne povrede u Krivičnom zakonu Srbije - osnovi koji isključuju njegovo postojanje [Serious bodily injury in the Criminal Code of Serbia - grounds, which exclude its existence. In Serbian]. Nauka, bezbednost, policija, 7(2), 75-85.

9. Livings, B. (2007). A Different Ball Game - Why the Nature of Consent in Contact Sports Undermines a Unitary Approach. The Journal of Criminal Law, 71(6), 534-566. Retrived 24.04.2016,fromhttps:// www.copyright.com/ccc/basicSearch.do?\&operation $=$ go \&searchType $=0$ \&lastSearch $=$ simple\&all $=$ on\&titleOrStdNo $=0022-0183$.

10. Mandarić, S., \& Delibašić, V. (2014). Sanction for doping in sport. Physical culture, 68(1), 39-49.

11. Marković, I. (2013). Körperverletzungen im sport - eine strafrechtliche gratwanderung. $U$ Đ. Ignjatović (ur.), Kaznena reakcija u Srbiji - III deo (pp. 295-308). Beograd: Pravni fakultet.

12. The International Federation of ice hockey Book rules 2014-2018. Retrived 03.05.2016, from http://www.srbreferee.com/upload iihf/Knjiga\%20pravila\%202014-18.pdf

13. Pausanija (1994). Opis Helade, tom II [Description of Greece. In Serbian]. Novi Sad: Matica Srpska.

14. Renson, R. (2009). Fair play: its origins and meanings in sport and society. Kinesiology, 41(1) 5-18. 


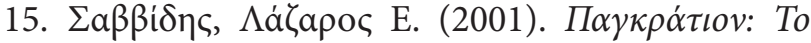

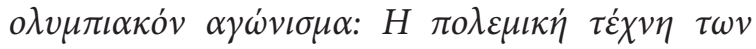

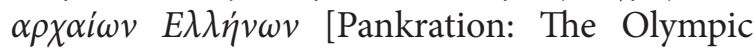
events: The martial art of the ancient Greeks. In

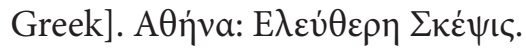

16. Stefanović, Đ. (2011). Filosofija, nauka, teorija $i$ praksa sporta [Philosophy, science, theory and practice of sport. In Serbian]. Beograd: Gnosis.

17. Stojanović, Z. (2012). Komentar Krivičnog zakon$i k a$ [Comment of the Criminal code. In Serbian]. Beograd: Službeni glasnik.

18. Stojanović, Z. (2015). Krivično pravo opšti deo [Criminal law general part. In Serbian]. Beograd: Pravni fakultet u Beogradu, Pravna knjiga.

19. Tyson, M., \& Sloman, L. (2013). Undisputed Truth. New York: Plume Book.
20. Harary, C. (2002). Aggressive Play or Criminal Assault? An In Depth Look at Sports Violence and Criminal Liability. Columbia Journal of Law \& the Arts, 25, 197-217.

21. Hosta, M. (2008). Ethics and sport: whose ethics, which ethos. Kinesiology, 40(1), 89-95.

22. Ceraj, S. (2005). Šport je za osobu, a ne obrnuto [Sport is for the person, not the other way around. In Slovenian]. Olimp, 17, 22-25.

23. Čeh, M. (2013). Etika i sport [Ethics and Sport. In Croatian]. In Findak V (ed.), Proceedings of the 22 summer school kineziologa Croatian Republic - organizational forms of work in the areas of education, sports, recreation, sports and physical training (pp. 404-408). Poreč: Croatian Kinesiology Association.

\title{
STRAFRECHTLICHER ASPEKT VON SPORTVERLETZUNGEN
}

\begin{abstract}
Zusammenfassung:
In dieser Arbeit wird der Begriff der Ethik im Sport definiert und darauf hingewiesen, dass Verhaltensformen existieren, die den Rahmen des Fair-Plays überschreiten. Im Rahmen der Arbeit werden ebenfalls der allgemeine Begriff der Straftat definiert, sowie Elemente des allgemeinen Begriffs der Straftat - Widerrechtlichkeit und Schuld - mit besonderer Beachtung der Grundlagen, die Widerrechlichkeit und Schuld, somit auch eine Straftat ausschließen. Besondere Aufmerksamkeit wird dem Einverständnis des Verletzten als Grundlage für die Ausschließung von Widerrechtlichkeit bei Sportwettbewerben gewidmet - mit der Betonung, dass mit seiner Zustimmung, an einem bestimmten Sport teilzunehmen, der Sportler nicht seine Zustimmung gibt, außerhalb eines für eine konkrete Sportart bestimmenden Rahmens verletzt zu werden. Es wird die Einstellung zum Ausdruck gebracht, dass der Sportler mit seiner Zustimmung die Möglichkeit akzeptiert, dass seine physische Integrität gefährdet wird, was immer noch nicht bedeutet, dass er damit einverstanden ist, wirklich verletzt zu werden, bzw. es wird ein Unterschied gemacht zwischen einer Folge, die aus einer Gefährdung besteht und einer Folge, die aus der Verletzung von Rechtsgut besteht. Die Arbeit weist auf Regeln hin, die für einzelne Sportarten gelten und in Verbindung mit dem Einverständnis des Verletzten gebracht werden. Es wird die Einstellung zum Ausdruck gebracht, dass das Einverständnis des Verletzten das Existieren einer Straftat nur dann ausschließt, wenn es zu einer Verletzung im Rahmen der Regeln einer konkreten Sportart gekommen ist. Wenn die Verletzung die Folge eines Verstoßes gegen die Sportregeln ist, handelt es sich um eine Straftat. In den Schlussbetrachtungen wird die Meinung vertreten, dass es eine Notwendigkeit ist, gegen alle schädlichen Erscheinungen im Sport anzukämpfen, somit auch gegen Verletzungen von Sportlern, die eine Folge von groben Verstößen gegen Regeln darstellen, die für einen konkreten Sport gelten. Die Schlussfolgerung weist darauf hin, dass die Zustimmung des Verletzten keine Entschuldigung für die Nichtanwendung des Strafrechts sein darf, wenn es zu einer Verletzung auf Grund von Verstößen gegen die Regeln einer Sportart gekommen ist.
\end{abstract}

Schlüsselwörter: ETHIK / FAIR-PLAY / STRAFTAT / ZUSTIMMUNG DES VERLETZTEN / AUSSCHLIEßUNG DER WIDERRECHTLICHKEIT / KÖRPERVERLETZUNG

Received: 10.05.2016.

Accepted: 02.11.2016.

(C) 2016 The Author. Published by Physical Culture (www.fizickakultura.com). This article is an open access article distributed under the terms and conditions of the Creative Commons Attribution license (http://creativecommons. org/licenses/by/3.0/rs/). 


\title{
КРИВИЧНОПРАВНИ АСПЕКТ ПОВРЕДА У СПОРТУ
}

\author{
Сања Мандарић ${ }^{1}$, Вељко Делибашић² \\ ${ }^{1}$ Факултет спорта и физичког васпитања, Универзитет у Београду \\ ${ }^{2}$ Адвокат из Београда
}

\begin{abstract}
Сажетак
У раду се дефинишу појам етике у спорту, и указује да постоје понашања која излазе из оквира фер-плеја, затим општи појам кривичног дела, као и елементи општег појма кривичног дела, противправност и кривица, с посебним освртом на основе који искључују противправност и кривицу, а самим тим и кривично дело. Посебна пажња посвећена је пристанку повређеног као основе искључења противправности на спортским такмичењима, уз наглашавање да својим пристанком да учествује у одређеном спорту, спортиста не даје пристанак да буде повређен изван оквира који успостављају правила конкретног спорта. Прихвата се став да се пристанком спортиста саглашава са могућношћу да његов физички интегритет буде угрожен, што још увек не значи да је дао сагласност да заиста буде повређен, односно прави се разлика између последице која се састоји у угрожавању и последице која се састоји у повреди заштићеног добра. Затим се указује на правила која важе у појединим спортовима, и доводе се у везу с пристанком повређеног, а заузима се став да пристанак повређеног искључује постојање кривичног дела само у ситуацији када је до повреде дошло у оквиру правила конкретног спорта. Уколико је до повреде дошло кршењем правила спорта, утолико би се радило о кривичном делу. У закључним разматрањима, заузима се став да је неопходно борити се против свих штетних појава у спорту, па тако и против повреда које настају повређивањем спортиста грубим кршењем правила која важе за конкретни спорт. Закључује се да пристанак повређеног не би смео да буде изговор за непримењивање кривичног права, када је до повреде дошло кршењем правила конкретног спорта.
\end{abstract}

КљУчне речи: ЕТИКА / ФЕР-ПЛЕЈ / КРИВИЧНО ДЕЛО / ПРИСТАНАК ПОВРЕЪЕНОГ / ИСКЉУЧЕЊЕ ПРОТИВПРАВНОСТИ / ТЕЛЕСНА ПОВРЕДА.

\section{УВОД}

Спорт као сложен и вишедимензионалан феномен, представља део укупне културе једног народа, који поред такмичења обухвата социјалне, психолошке, педагошке, медицинске, економске, научне, културне, правне, политичке и друге вредности (Стефановић, 2011). Поред тога, спорт се може сагледати са аспекта позитивног и негативног становишта. Позитивно становиште о спорту засновано је на ставу да је он, између осталог, најважнији културни феномен савременог друштва, механизам личне и социјалне афирмације, групне идентификације, испољавање заједништва, који уједно представља културу тела, естетску „ствар“, али и манифестовање стила младих. С друге стране, негативно становиште засновано је на ставу, да је спорт подручје високог ризика, изражавање нагона супарништва, деформисани облик игре, простор насиља и манипулисања маса (Ковачевић, 2011).
У складу с тим, може се рећи да, поред користи од спорта која је неспорна, пре свега за оне који се спортом ठаве, управо су спортисти изложени и штетним појавама које прате спорт, у које свакако спадају и повреде. При томе, до повреда долази услед различитих узрока, како у оним спортовима чија правила не дозвољавају повреду противника, на пример, фудбал, кошарка, одбојка, рвање, џудо, атлетика и слично, тако и у оним спортовима чија правила дозвољавају повређивање противника у склопу надметања а у циљу победе, на пример, бокс, кик-бокс, ММА, и други.

У савременом друштву, узрок повреда спортиста, без обзира на спортску грану може бити повезано са агресивним и насилничким понашањем спортиста током такмичења. Чињеница је, да је у данашњем савременом свету, жеља за успехом нераскидиво повезана са стицањем профита, па се спортско такмичење претвара у агресивну борбу за резултат и престиж. У професионалном спорту, 
у коме је победа императив, такмичари често третирају друге само као објекат и препреку коју треба савладати (Hosta, 2008). Тако поједини спортисти током такмичења испољавају неконтролисано понашање, које се одликује грубошћу, агресивношћу и непостојањем спортске етике и фер-плеја, које није у складу са правилима такмичења. Овакво понашање спортиста током такмичења на самом терену, могу имати за последицу повређивање противника, али и далекосежне социолошке последице на публику и младе људе који у спортским звездама траже своје узоре (Божовић, 2007).

Општа обавезност примењивања кривичног права у области спорта, па и када су у питању телесне повреде које су настале током спортске манифестације, не може се довести у питање. Оно што намеће мноштво правних питања јесте њихова кривично-правна оцена и квалификација. Постоји више приступа за решавање овог проблема (пристанак повређеног, друштвена прихватљивост, дозвољени ризик, искључење противправности у спортским манифестацијама, правни вакум), али због разноврсности ситуација у спорту у којима може доћи до телесних повреда, потребно је узети у обзир сваки од наведених да би се формирала права слика. Редослед је следећи: при игри која се одвија у складу са правилима некажњавање се може правдати друштвеном прихватљивошћу, блаже повреде правила покрива дозвољени ризик, тежа повреда правила захтева пристанак повређеног, а код намерно нанесених телесних повреда граница између дозвољеног у спорту и недозвољене повреде је јасно прекорачена и захтева кривично санкционисање (Марковић, 2013).

\section{ЕТИКА У СПОРТУ}

У данашње време, спорт карактерише недовољно поштовање општепризнатих правила понашања, па се често током спортских такмичења уочава непридржавање начела која су карактеристична за спорт и спортско такмичење. Из тог разлога, питање етике и проблем морала у спорту, заузима једно од значајних места на скали друштвених питања и вредности, односно на скали функционисања и изградње квалитетних друштвених односа.

Када се спомињу и повезују термини етика и спорт, тачније етика у спорту најчешће се помисли на негативне аспекте спорта. Чињеница је да смо сведоци бројних неетичких елемената везаних за спорт, као што су допинг, мито и коруп- ција, унапред „продане” утакмице, агресивно и насилничко понашање, као и међусобно вређање спортиста и тренера по различитим основама. (Brkljačić, 2007; Мандарић, и Делибашић, 2014; Делибашић, и Мандарић, 2015)

Етика (грч. ё $\bar{u} x о c-$ обичај) заједно са естетиком спада у заједничку област филозофије, проистеклих из тзв. практичне филозофије, која се назива аксиологија или теорија вредности. Као област филозофије, етика се ठави проучавањем и процењивањем морала, односно појмова добро и исправно. Свака етичка теорија садржи бар две компоненте, ону која одређује шта је добро или вредно, и ону која одређује шта је исправно. У складу с наведеним, може се рећи да морал представља један облик друштвене свести, који у пракси подразумева нешто што је добро са аспекта међуљудских односа, и односа појединца према друштву као целини. С тим у вези, моралне вредности представљају скуп, нарочито, добрих норми или правила људског понашања.

Како се друштво креће, развија, структуира, тако се мењају и изграђују морална схватања, моралне норме и етички садржаји свести. На место старих, раније важећих норми понашања, у измењеним друштвеним околностима, стварају се нови погледи и настају нова схватања, нови вредносни судови и системи, односно нове моралне вредности. У складу с тим, може се рећи да морал није ванвременски и непроменљив, и да не постоји један опште важећи морал који је прихваћен у свим друштвима и временима (Стефановић, 2011).

Када је у питању етика у спорту, може се рећи да она представља примену општепознатих моралних вредности на саме ситуације у спорту и спорт у целини (Ceraj, 2005), односно понашање спортиста према разним међународним и националним кодексима понашања, која су морално релевантна. Другим речима, спортски морал представља низ правила вредносног понашања спортисте, које он исказује у свим сегментима спорта. Међутим, чињеница је, да је спортско такмичење простор, у којем се више него било где, могу проверити моралне вредности у односима људи. С обзиром да је спорт област личних и групних подвига и пораза, у њему се и највише уочавају моралне иницијативе али и морални падови (Стефановић, 2011).

Основе вредносног понашања спортисте, могу се пронаћи у темељима грчких етичких начела, према којима су, на основу навода Платона, основне врлине које обележавају једног врхунског спортисту мудрост, храброст, умереност и пра- 
ведност (С̌eh, 2013). У античкој Грчкој је постојао етички кодекс понашања, којег су се придржавали панкратионисти (такмичари у панкратиону, који представља спој рвања и бокса). Панкратионисти су, према овом кодексу, морали да сачувају живот противника, смилују се на све што постоји, буду посвећени, часни, истинити, праведни према свима и гостољубиви према непознатима. Сваки панкратиониста морао је да буде племенит, праведан, скроман и достојанствен $(\Sigma \alpha \beta \beta i \delta \eta \varsigma, 2001)$.

Може се рећи да спортски морал, односно у ширем значењу спортска етика, јесте скуп норми или правила, која регулишу односе и одређују понашање људи у спорту одређујући ближе моралне дужности чланова спортских организација према друштву, према спорту и односе појединаца у њему (Стефановић, 2011).

Морал се у спорту изражава кроз фер-плеј, под којим се подразумева часно надметање или витештво. Фер-плеј је светски познат концепт, који се развио у деветнаестом веку упоредо са развојем модерног спорта у Великој Британији, и у великој мери одражава енглески спортски начин живота, као и њихово виђење надметања у спорту (Renson, 2009). Основна начела фер-плеја састоје се у поштовању правила такмичења, противника и судиjа. У складу с тим, спортисти би требало да поштују противника и не би требало да се служе нечасним средствима. Када побеђују спортисти никада не би требало да вређају противника, а када губе, требало би да знају да сачувају своје достојанство, а противнику одају признање због победе.

Начела фер-плеја оснивача модерних олимпијских игара, барона Пјер де Кубертена, имају своје посебно значење у контексту етике у спорту, а подразумевају развијање коректних, другарских односа међу спортским супарницима, поштовање правила и судијских одлука, развијање активизма да би се оплеменила спортска борба у такмичењу, усклађивање личних потреба и интереса са потребама и интересима екипе, клуба и репрезентације, развијање антиколонијалног, антирасистичког и антинационалнистичког става у ширим спортским такмичењима (Kozarčanin, 2008).

У данашње време се на спортским такмичењима могу видети понашања спортиста, која нису у складу са начелима етике у спорту и фер-плеја. Тако је потез француског репрезентативца Зинедина Јазида Зидана (Zinedine Yazid Zidane), десет минута пре краја финалне утакмице на Светском првенству у Немачкој 2006, запањио фудбалски свет и бацио сенку на финални меч. Наиме, Зидан је дисквалификован у другом полувремену утакмице јер је главом ударио италијанског репрезентативца Марка Матерација (Marco Materazzi). Након инцидента, снимак утакмице је показао да су Зидан и Матераци, после једне неуспеле акције француске репрезентације, нешто разговарали, после чега је Зидан почео да се удаљава. Међутим, Матераци је даље наставио да прича, након чега се Зидан вратио до њега и ударио га главом. Дисциплинска комисија Светске фудбалске федерације казнила је Матерација са пет хиљада швајцарских франака, јер је признао да је увредио Зидана, док је Зидан завршио своју спортску каријеру неспортским понашањем. Међутим, спортска биографија Зинедина Зидана указује да је он често био санкционисан током утакмица услед грубе и оштре игре, грубих прекршаја и ударања руком противничког играча. Оваква и слична непоштовања етике и фер-плеја доводи до понашања које губи позитивне карактеристике, а која индиректно утичу на назадовање спорта.

\section{ОПШТИ ПОЈАМ КРИВИЧНОГ ДЕЛА}

Кривични законик прописује да је кривично дело оно дело које је законом предвиђено као кривично дело, које је противправно и које је скривљено (члан 14. став 1. К3). То значи да општи појам кривичног дела обухвата четири конститутивна елемента: дело, предвиђеност у закону, противправност и кривицу. Ова четири елеманта су истовремено четири степена која карактерише прогресивност приликом њиховог утврђивања у конкретном случају, што треба да допринесе и бољој и исправнијој примени кривичног права. Редослед појединих елемената Кривични законик не даје произвољно и он се не може мењати, а да не дође до неприхватљивих теоријских и практичних последица. Наиме, постепеност у утврђивању остварености наведена четири елемента веома је важна. Приликом решавања конкретних случајева и примене кривичног права, увек се почиње радњом (делом), а завршава кривицом. Према томе, четири обавезна елемента у појму кривичног дела истовремено представљају и четири степена, или нивоа кроз која се мора проћи да би се на крају могло констатовати да је учињено кривично дело (Стојановић, 2012).

Прво се утврђује да ли нека радња испуњава услове који се захтевају за радњу кривичног дела. 
На том првом нивоу, по правилу, само мањи део радњи неће испунити минималне услове који се постављају за радњу кривичног дела. Међутим, већ на следећем нивоу или степену, приликом утврђивања да ли су испуњена битна обележја законског описа одређеног кривичног дела, долази до значајног сужавања круга радњи путем којих су остварени сви законски услови за постојање одређеног кривичног дела. Предвиђеност у закону јесте елемент у општем појму кривичног дела који изузетно велики број људских радњи, које би потенционално могле бити радња кривичног дела, своди на један релативно ограничен круг радњи. Оствареност свих обележја предвиђених у законском опису одређеног кривичног дела још не значи постојање кривичног дела, па чак ни кривичног неправа. За такво понашање, иако постоје не само јаке индиције за то, већ се може рећи да је тиме по правилу његова противправност конституисана, још не можемо дефинитивно казати да представља кривично неправо, тј. да је противправно у кривичноправном смислу. До утврђивања противправности долази на следећем нивоу. Утврђује се, у ствари, није ли искључена противправност неког понашања које испуњава сва законска обележја неког кривичног дела (на пример, није ли лишење живота неког лица учињено у нужној одбрани и друго). Тек уколико не постоји неки од основа који искључују противправност, може се констатовати да је учињено кривично неправо, да постоји кривично дело у непотпуном, објективном смислу. Најзад, за постојање кривичног дела потребно је утврдити и кривицу учиниоца. То је последњи ниво на коме се доноси одлука и коначна оцена о томе да ли је у конкретном случају учињено кривично дело. Три прва (објективна) елемента могу постојати без четвртог, тј. кривице, али никако обрнуто: нема кривице уколико нису остварени објективни елементи (Стојановић, 2012).

\section{ПРОТИВПРАВНОСТ И КРИВИЦА}

Одрећеност људског понашања у кривичном закону као кривичног дела, по правилу, значи и његову противправност. Уколико неко понашање садржи све елементе прописане у законском опису бића кривичног дела, самим тим је то понашање и противправно. Противправности у кривичном праву нема уколико нема предвиђености дела у закону као кривичног дела. Изузетно, противправ- ност може бити искључена, због чега би дело, иако је у закону одрећено као кривично дело, изгубило карактер кривичног дела. Разлог за уношење противправности као конститутивног елемента у општи појам кривичног дела јесу управо основи искључења противправности, па би се елемент противправности у том појму могао одредити у негативном смислу као одсуство основа који искључују противправност (Стојановић, 2015).

Кривица постоји ако је учинилац у време када је учинио кривично дело био урачунљив и поступао са умишљајем, а био је свестан или је био дужан и могао бити свестан да је његово дело забрањено (члан 22. став 1. К3). Кривично дело је учињено са кривицом и ако је учинилац поступао из нехата, уколико закон то изричито предвиђа (члан 22. став 2. К3).

Умишљај је тежи степен кривице и он се увек захтева за постојање кривичног дела. Изузетно, код неких кривичних дела, предвиђен је и нехат као блажи облик кривице, тј. прописује се лакши облик одређеног кривичног дела с обзиром на степен кривице. Из законске дефиниције умишљаја (dolus) произлазе две врсте умишљаја: директни и евентуални (члан 25. К3). Према тој дефиницији кривично дело је учињено са директним умишљајем онда кад је учинилац био свестан свог дела и хтео његово извршење, а евентуални умишљај постоји онда кад је учинилац био свестан да може учинити дело, па је на то пристао.

Нехат (culpa) је лакши облик, односно нижи степен кривице у односу на умишљај. У случају када закон предвиђа и нехатни облик неког кривичног дела, прописана казна увек је блажа у односу на умишљајни облик. Иначе, закон познаје две врсте нехата: свесни и несвесни (члан 26. К3). Свесни нехат (luxuria) постоји онда када је учинилац био свестан да својом радњом може учинити дело, али је олако држао да до тога неће доћи или да ће то моћи спречити. Код свесног нехата закон говори о две ситуације где се, у првој, учинилац поуздаје у своје способности које прецењује, а у другој, погрешно процењује објективну ситуациjу. У оба случаја он, међутим, за разлику од евентуалног умишљаја, не пристаје на последицу. Несвесни нехат (negligentia) постоји када учинилац није био свестан да својом радњом може учинити дело иако је према околностима под којима је оно учињено и према својим личним својствима био дужан и могао бити свестан те могућности.

Посебно је важно утврдити о ком облику умишљаја или нехата се ради јер од тога зависи од- 
говор на читав низ питања, почев од тога да ли се уопште ради о кривичном делу и којем, до изрицања одговарајуће кривичне санкције. Док су проблеми разграничења између директног и евентуалног умишљаја мање изражени и по правилу нису од пресудног значаја, један од најважнијих проблема код умишљаја, па и кривице у целини, јесте разграничење евентуалног умишљаја и свесног нехата. Наиме, елемент свести је исти, а разлика постоји у погледу елемента воље: код евентуалног умишљаја учинилац пристаје да учини кривично дело, док код свесног нехата он неће наступање последице, односно не пристаје да учини кривично дело. То значи да се законодавац, између више теорија које настоје да реше овај проблем, определио за теорију пристајања. Пристајање треба ценити пре свега у односу на последицу кривичног дела јер се, по правилу, у спорним случајевима ради о последичним кривичним делима. Наиме, нехатна кривична дела су скоро искључиво последична кривична дела (Стојановић, 2015).

\section{ОСНОВИ ИСКЉУЧЕЊА ПРОТИВПРАВНОСТИ И КРИВИЦЕ}

Нема кривичног дела уколико је искључена противправност или кривица, иако постоје сва обележја кривичног дела одређена законом (члан 14. став 2. К3). Постоје три основа искључења противправности, а тиме и кривичног дела прописана Кривичним закоником, а то су: дело малог значаја, нужна одбрана и крајња нужда. Тако, није кривично дело оно дело које, иако садржи обележја кривичног дела, представља дело малог значаја (члан 18. став 1. К3), а оно је малог значаја ако је степен кривице учиниоца низак, ако су штетне последице одсутне или незнатне и ако општа сврха кривичних санкција не захтева изрицање кривичне санкције (члан 18. став 2. К3). Ове одредбе могу се применити на кривична дела за која је прописана казна затвора до пет година или новчана казна (члан 18. став 3. К3). Такође, није кривично дело оно дело које је учињено у нужној одбрани (члан 19. став 1. КЗ), а нужна је она одбрана која је неопходно потребна да учинилац од свог добра или добра другога одбије истовремен противправан напад (члан 19. став 1. КЗ). Поред тога, није кривично дело ни оно дело које је учињено у крајњој нужди (члан 20. став 1. К3), а она постоји кад је дело учињено ради тога да учинилац отклони од свог добра или добра другога истовремену нескривљену опасност која се на други начин није могла отклонити, а при томе учињено зло није веће од зла које је претило (члан 20. став 2. КЗ).

Осим ова три основа искључења противправности које предвиђа Кривични законик, постоји и већи број других основа искључења противправности предвиђених другим прописима, или који произилазе из ставова доктрине и судске праксе. То су: вршење службене дужности, наређење претпостављеног, пристанак повређеног, дозвољени ризик (овај основ је споран), право на дисциплинско кажњавање малолетне деце од стране родитеља и предузимање медицинских захвата.

Основи искључења кривице, а тиме и кривичног дела су компулзивна (неодољива) сила (члан 21. К3), неурачунљивост (члан 23. К3), неотклоњива стварна заблуда (члан 28. К3) и неотклоњива правна заблуда (члан 29. К3). С тим у вези, неурачунљив је онај учинилац који није могао да схвати значај свог дела или није могао да управља својим поступцима услед душевне болести, привремене душевне поремећености, заосталог душевног развоја или друге теже душевне поремећености. Стварна заблуда је неотклоњива ако учинилац није био дужан и није могао да избегне заблуду у погледу неке стварне околности која представља обележје кривичног дела или у погледу неке стварне околности која би, да је заиста постојала, чинила дело дозвољеним. Правна заблуда је неотклоњива ако учинилац није био дужан и није могао да зна да је његово дело забрањено.

\section{ПРИСТАНАК ПОВРЕБЕНОГ КАО ОСНОВ ИСКЉУЧЕЊА ПРОТИВ- ПРАВНОСТИ НА СПОРТСКИМ ТАКМИЧЕЊИМА}

Закон о спорту дефинише спорт као делатност од посебног значаја за Републику Србију, која је део физичке културе који обухвата сваки облик организованог и неорганизованог обављања спортских активности и спортских делатности од стране физичких и правних лица у систему спорта, у циљу задовољења потреба човека за стваралаштвом, афирмацијом, физичким вежбањем и такмичењем са другима. Спортске активности јесу сви облици физичке и умне активности који, кроз неорганизовано или организовано учешће, имају за циљ изражавање или побољшање 
физичке спремности и духовног благостања, стварање друштвених односа или постизање резултата на такмичењима свих нивоа, док су спортске делатности оне којима се обезбеђују услови за обављање спортских активности, односно омогућава њихово обављање, а нарочито: организовање учешћа и вођење спортских такмичења, укључујући и међународна такмичења, обучавање за бављење спортским активностима и планирање и вођење спортских активности; спортско суђење; организовање спортских припрема и спортских приредаба; обезбеђење и управљање спортском опремом и објектима; стручно образовање, оспособљавање, усавршавање и информисање у области спорта; научноистраживачки и истраживачко-развојни рад у спорту; пропаганда и маркетинг у спорту; саветодавне и стручне услуге у спорту; спортско посредовање, организовање пословања организација у области спорта.

Лица која се баве спортом, без обзира на то да ли је реч о професионалном, аметерском или рекреативном спорту, током спортских активности и делатности, могу извршити радње које се подводе под радњу појединих кривичних дела против живота и тела, и тада се поставља питање да ли уопште постоји и које конкретно кривично дело, односно ако се не ради о кривичном делу који је основ искључења кривичног дела у тој ситуацији. Одговор на ова питања зависиће од сваког конкретног случаја, а пре свега од тога да ли је до извршења радње дошло у оквиру правила конкретног спорта, да ли постоји неки основ искључења противправности или кривице, односно кривичног дела. Најчешће се ради о кривичним делима лака телесна повреда (члан 122. К3), тешка телесна повреда (члан 121. К3), убиство (члан 113. К3), нехатно лишење живота (члан 118. К3) и учествовање у тучи (члан 123. К3).

Пристанак повређеног, као општи институт који искључује противправност, треба разликовати од случајева када једноставно нису испуњени елементи неког кривичног дела зато што пристанак лица према којем се неке радње предузимају искључују принуду као битан елемент тих кривичних дела (на пример, пристанак је неспојив са кривичним делом разбојништва, силовања, изнуде итд), или се због пристанка дело не врши неовлашћено, што је код неких кривичних дела обавезан елемент (на пример, кривично дело повреде тајности писама или других пошиљки или неовлашћено откривање тајне од стране адвоката или лекара). За разлику од наведене ситуације где не постоји предвиђеност у закону као елемент општег појма кривичног дела, овде је реч о томе да ли пристанку повређеног дати карактер општег основа искључења противправности. Сасвим је сигурно да се код неких кривичних дела, односно заштите одређених добара за чију је заштиту заинтересовано друштво у целини, не може дати право појединцу да одлучује о томе да ли ће кривично дело бити искључено. То и јесте централни проблем код пристанка повређеног као основа искључења противправности: где повући границу између кривичних дела за која је друштво апсолутно заинтересовано, и оних где би се евентуално могло дозволити пасивном субјекту да својим пристанком искључи њихову противправност. Код неких личних добара, која се рангирају веома високо, постоји изразит друштвени интерес, тако да се не би могло препустити појединцима да о њима одлучују без обзира на то што су они њихови непосредни носиоци (на пример, право на живот). Посредно, законодавац признаје значај пристанка повређеног тако што код одређених кривичних дела предвића кривично гоњење по приватној тужби, тј. од воље повређеног зависи да ли ће доћи до примене кривичног права (Стојановић, 2015). Тако на пример, за (обичну) лаку телесну повреду из члана 122. став 1. Кривичног законика, гоњење се предузима по приватној тужби.

Велика могућност и вероватноћа наношења телесних повреда при спортским активностима указују на нужност примене института пристанка повређеног при утврђивању одговорности за нанете повреде (Коларић, 2002). Тако пристанак повређеног има значаја нарочито код неких спортова код којих учесници прихватају могућност евентуалних повреда. Кривично дело ће бити искључено уколико је повреда нанета у оквиру правила неког спортског такмичења. Ту су могуће две ситуације: или је повреда сама по себи дозвољена (на пример, у боксу), или је повреда уобичајена и кажњава се у оквиру правила игре (фаул у фудбалу). Напротив, ако је до ње дошло умишљајно, или ако је она нанета не у оквирима правила спорта, него из неких других разлога и мотива, кривично дело ће постојати (Стојановић, 2015).

С тим у вези, треба правити разлику између понашања која су разумно предвиђена када се учествује у спорту и понашања која нису предвиђена. Учествовањем у спорту, лице даје пристанак на радње које су разумно предвиђене у одређеном спорту (Harary, 2002). Другим речима, треба најпре приметити да пристанак на угрожавање не подразумева и пристајање на наступање последице, већ 
је више реч о саглашавању са једном опасном радњом. Из чињенице да је неко лице пристало да буде изложено одређеном ризику не може се извући далекосежан закључак да је оно пристало да буде повређено. Отуда саглашавање са стадијумом угрожавања не подразумева аутоматски и саглашавање са стадијумом повреде, па сличан пристанак може да искључи противправност само деликта угрожавања. Тако се у сфери спорта сматра прихватљивим пристанак на нехатно угрожавање телесног интегритета (Вуковић, 2013).

Дакле, може се прихватити став да подразумевани пристанак треба дозволити само у ограниченим околностима. Наиме, играч може дати подразумевани пристанак на одређене предвидљиве форме спортског контакта које могу представљати кривични напад да су се одиграли ван спортског терена. Међутим то не значи да играч пристаје на намерно наношење повреда које су изван оквира предвидљивости у такмичарској игри, односно, ниједан контакт који је изван граница игре се не може подвести под пристанак (Harary, 2002). При томе се одговорност не утврђује субјективно, у смислу да је жртва упућена и тако дала пристанак, већ се утврђује према објективним стандардима и у складу са правилима одређеног спорта. То значи да су учесници пристали на оно што се подразумева у уобичајеном току игре, па пристанак произилази из оцене околности под којима се догађај одиграо (Livings, 2007).

На крају треба рећи, да до озбиљног нарушавања здравља спортисте, што у кривичноправном смислу може представљати тешку телесну повреду, а има случајева у којима је дошло и до смртне последице, може доћи и употребом допинг средстава (Мандарић, и Делибашић, 2014; Делибашић, и Мандарић, 2014). У случају када је остварено биће кривичног дела омогућавање употребе допинг средстава из члана 38. Закона о спречавању допинга у спорту, пристанак спортисте је ирелевантан за постојање кривичног дела. У том случају, пристанак спортисте би могао да се узме само као олакшавајућа околност приликом одмеравања казне.

\section{ПРАВИЛА ПОЈЕДИНИХ СПОРТОВА И ПРИСТАНАК ПОВРЕТЕНОГ}

Постоји подела спортова према различитим критеријумима, а једна од подела је и подела на контактне и неконтактне спортове. Контактни спортови су они спортови, у којима противнички играчи имају физички контакт током и у оквиру правила игре (рукомет, кошарка, ватерполо, фудбал, рагби, џудо, рвање, бокс, и други), а у неконтактним спортовима нема физичког контакта између такмичара (стони-тенис, тенис, бадминтон, одбојка, атлетика, куглање, бициклизам, аутомобилизам и други). Када је реч о могућностима повређивања, основна подела спортова је на спортове у којима је повреда дозвољена и на оне у којима није. При томе, треба посебно имати у виду да у оним спортовима у којима је повреда дозвољена, није дозвољена свака повреда, односно није дозвољен сваки начин повређивања.

Познато је да је још у периоду античке Грчке, током спортских надметања, било дозвољено повређивање противника у тркама двоколица и борилачким спортовима, у којима се скоро славило насиље, односно повређивање противника. У том периоду борилачки спортови су имали мало граница и ограничења. Тако су у боксу били дозвољени сви ударци, директо у лице, гениталије, тело, одозго, а једино није било дозвољено копање очију и угризи. У рвању су били дозвољени сви захвати, чак и ломљење прстију противка (Паусанија, 1994).

Лака телесна повреда је могућа у свим контактним спортовима, а ту спадају огреботине, огуљотине, модрице, и лакше повреде мишића и костију. По правилу, тада се неће радити о кривичном делу, осим ако лака телесна повреда није нанета намерно и понашањем које није дозвољено правилима конкретног спорта. Тако на пример, у фудбалу није дозвољено уједати противничке играче, што је Луис Суарез (Luis Suárez) у више наврата урадио, чиме је извршио кривично дело лаке телесне повреде. Овде треба имати у виду да се за лаку телесну повреду гони по приватној тужби, што даље значи да од воље оштећеног зависи да ли ће доћи до покретања кривичног поступка, а самим тим и до осуде за лаку телесну повреду.

Идентична је ситуација у боксу, где је дозвољено наносити повреде противнику у оквиру правила бокса, односно дозвољено је повредити противника ударцем затвореном шаком која се налази у боксерској рукавици али није дозвољено повредити противника ударцем ногом или га угристи, што је учинио Мајк Тајсон (Michael - Mike Tyson) у борби са титулу првака света, када је одгризао парче увета Холифилду (Evander Holyfield), током меча одржаног 1998. у Лас Вегасу. Том приликом, Мајк Тајсон је диквалифико- 
ван, а у својој аутобиографској књизи написао, да је свестан шта је учинио, али да у тренутку борбе није размишљао о боксу и да је његов потез реакција на бес услед удараца главом које је добијао од Холифилда (Tyson, \& Sloman, 2013). У овом примеру се не може применити институт пристанка повређеног као основ искључења противправности, односно кривичног дела, јер Холифилд, који је дао пристанак да буде повређен у оквирима правила бокса, свакако није дао пристанак да буде грижен, тј. да му противник одгризе уво. То даље значи да је кривично дело извршено и да има места пуној примени кривичног права.

За правилну примену института пристанка повређеног, посебно је важно одговорити на питање да ли је одређено понашање дозвољено или забрањено у оквиру конкретног спорта. Од тога може зависити одговор на питање да ли постоји кривично дело или не, односно да ли то што постоји санкција за одређено понашање у оквиру конкретног спорта, искључује или не искључује постојање кривичног дела. Тако на пример, фаулирати противника у фудбали није дозвољено, односно у фудбалу је забрањено, па се у случају кршења те забране изриче одговарајућа санкција у оквиру те игре, односно кажњава се фаулом (прекршајем), уз који се може доделити жути или црвени картон, што све представља санкцију у оквиру игре. Зато би могао да се заступа став да понашање које је забрањено правилима игре, па и она понашања за која сама правила игре прописују одређену санкцију (спортску), не искључују постојање кривичног дела. Другим речима, уколико дође до лаке или тешке телесне повреде приликом фаула у фудбалу, могао би се заступати став да се ради о кривичном делу, будући да и сама фудбалска игра не дозвољава такво понашање.

Слична је ситуација и са другим спортовима, на пример, хокејом на леду, где је дозвољено ударити боком или раменом играча који у том тренутку има плочицу или ју је имао непосредно пре, али није дозвољено уједати било који део тела противничког играча, ударити истуреним делом штапа противника, напасти противника непотребном силом или се залетети и скочити на противника, односно напасти га с леђа. Уједно, није дозвољно ударати било којим делом тела или опреме, у главу или врат противничког играча или набијати главу противничког играча у заштитно стакло или ограду, користити лакат или колено за фаулирање противника, замахнути клизаљком према противнику, а најстроже је забрањено ударати шта- пом, као што није дозвољен и било какав физички контак са судијом (Књига правила 2014-2018).

Ипак, треба рећи да се фаул у фудбалу или хокеју може подвести под шири појам правила игре, односно да се у фудбалу, хокеју и другим спортовима дозвољава фаулирање противника и за то следи санкција у оквирима саме игре. Једино, ако би се драстично изашло из оквира правила игре, на пример, погибељни старт на противничког фудбалера, не би се могло прихватити да правила фудбала то на било који начин дозвољавају. Тиме пре, понашања која су неспорно и строго забрањена, на пример, ударање противника без лопте, која се санкционишу од стране спортског судије, представљају кривично дело. С тим у вези, може се бранити став да постоји пристанак оштећеног да буде фаулиран у оквиру ширег схватања правила спорта, па би то могао да буде основ искључења кривичног дела. Међутим, спортисти не дају сагласност да буду повређени радњама које драстично излазе из оквира чак и ширег тумачења правила игре, па самим тим, уколико дође до повреда које су обележје неког кривичног дела, оно би постојало. С тим у вези, треба нагласити да би се ипак, у коначности, одговор на питање да ли се ради о кривичном делу или не, уз институт пристанак повређеног, требало тражити на плану свести, односно умишљаја и нехата код учиниоца.

\section{ЗАКЉУЧАК}

Спорт је корисна друштвена делатност, која производи многе позитивне ефекте, пре свега за оне који се спортом ठаве. Поред неспорних користи које спортисти имају од бављења спортом, они су изложени и штетним појавама које прате спорт, у које спадају и повреде, а до којих може доћи у оквиру правила конкретног спорта, али и кршењем тих правила. У ситуацији када дође до повреде спортисте, поставља се питање да ли се ради о неком кривичном делу, односно, ако се заузме став да није реч о кривичном делу, који је основ искључења кривичног дела. По правилу, тада долази у обзир примена института пристанка повређеног, који искључује противправност, а самим тим и кривично дело.

Пристанак повређеног се примењује у случају када је до повреде дошло у оквирима правила конкретног спорта, али се овај институт не може применити када до повређивања противника 
дође услед радње која излази из оквира правила конкретног спорта (на пример, ударац ногом у боксу). Тада се мора применити кривично право, jep је неопходно борити се против свих штетних појава у спорту, па тако и против повреда, нарочито оних које настају повређивањем спортиста грубим кршењем правила која важе за конкретни спорт. С тим у вези, пристанак повређеног не би смео да буде изговор за непримењивање кривичног права, када је до повреде дошло умишљајним кршењем правила конкретног спорта.

Наиме, овај институт је могуће применити само када је учинилац нехатно повредио противника у оквиру правила конкретног спорта, који обухвата шири појам, односно појам који садржи и “дозвољене" прекршаје у конкретном спорту (фаул у фудбалу). Такође, пристанак повређеног се примењује код повреда нанетих у оним спортовима чија правила дозвољавају повређивање противника у оквиру надметања а у циљу победе (бокс, кик-бокс, ММА и други), али само за повреде настале у складу с правилима тог спорта, јер је

\section{ЛИТЕРАТУРА}

1. Божовић, Р. (2007). Агресија и насиље у спорту. Сочиолочка луча, I(2), 100-112.

2. Бркљачић, М. (2007). Етика и спорт. Меgиนина, 43, 230-233.

3. Вуковић, И. (2013). Пристанак повређеног као основ искључења противправности. У Ђ. Игњатовић (ур.), Казнена реакиија у Србији - III geо (стр. 175-186). Београд: Правни факултет.

4. Делибашић, В., и Мандарић, С. (2014). Кривичноправно сузбијање допинга у спорту. Ойт̄yжене и яруїи кривичнойравни инстируменити gржавне реакиије на криминалитетеи (стр. 575590). Златибор: LIV Редовно годишње саветовање Српског удружења за кривичноправну теорију и праксу.

5. Делибашић, В., и Мандарић, С. (2015). Насилничко понашање на спортској приредби или јавном скупу. Кулиичра йолиса, 12, посебно издање, 79-92.

6. Ковачевић, Б. (2011). Друштво, насиље и спорт. Насиље и сиорй- Зборникраяов а са међунарояної научноі скуйа на йему „Млаgи и насиље у сйорйу у Рейублици Срииској - Босни и Хериееіовини и објезбеђете сиооричских gоїађаја (стр. противник пристао само на те повреде, а никако и на повреде које су настале кршењем правила (на пример, повређивање противника који се предао, након што је судија прекинуо борбу, забрањеним ударцем и слично).

За кривичноправи аспект повреда у спорту важно је и питање свести, односно умишљаја и нехата који постоји код учиниоца, од чега ће зависити да ли ће постојати кривично дело и које, односно да ли ће се применити институт пристанка повређеног или неће. Наиме, од тога ће зависити, на пример, да ли се ради о неком облику тешке телесне повреде из члана 121. став 1, 2. или 3. К3 (умишљајна тешка телесна повреда) или из члана 121. став 4. К3 (нехатна тешка телесна повреда).

У сваком случају институт пристанка повређеног је непримењив у ситуацији када је до повреде дошло грубим кршењем правила конкретног спорта, и тада ће постојати кривично дело, односно, неопходна је примена кривичног права на конкретни догађај.

38-46). Бања Лука: Европски дефендологија центар за научна, политичка, економска, социјална, безбједносна, социолошка и криминолошка истраживања.

7. Kozarčanin, A. (2008). Etika u sportu. Sport Science, 1(1), 54-56.

8. Коларић, Д. (2002). Кривично дело тешке телесне повреде у Кривичном закону Србије основи који искључују његово постојање. Нау$\kappa a$, бездеgносй, йолищија, 7(2), 75--85.

9. Livings, B. (2007). A Different Ball Game - Why the Nature of Consent in Contact Sports Undermines a Unitary Approach. The Journal of Criminal Law, 71(6), 534-566. Доступно 24.04.2016, на https:// www.copyright.com/ccc/basicSearch.do?\&operat ion=go\&searchType $=0$ \&lastSearch $=$ simple \&all $=0$ n\&titleOrStdNo=0022-0183.

10. Мандарић, С., и Делибашић, В. (2014). Санкционисање допинга у спорт. Физичка кулйиpa, 68(1), 39-49.

11. Марковић, И. (2013). Körperverletzungen im sport - eine strafrechtliche gratwanderung. $\mathrm{y} \mathrm{h}$. Игњатовић (ур.), Казнена реакиија у Србији - III geо (стр. 295-308). Београд: Правни факултет. 
12. Међународна федерација хокеја на леду - Књига правила 2014-2018. Доступно 03.05.2016, на http://www.srbreferee.com/upload iihf/ Knjiga\%20pravila\%202014-18.pdf

13. Паусанија (1994). Ойuс Хелаgе, йом II. Нови Сад: Матица Српска.

14. Renson, R. (2009). Fair play: its origins and meanings in sport and society. Kinesiology, 41(1) 5-18.

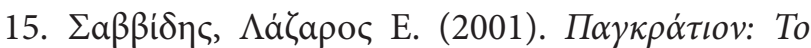

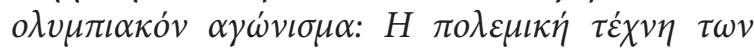

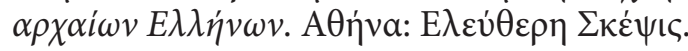

16. Стефановић, Ђ. (2011). Философија, наука, иееорија и йракса сйорйа. Београд: Гносис.

17. Стојановић, 3. (2012). Коменитар Кривичноі законика. Београд: Службени гласник.

18. Стојановић, 3. (2015). Кривично йраво ойшӣu gео. Београд: Правни факултет у Београду, Правна књига.
19. Tyson, M., \& Sloman, L. (2013). Undisputed Truth. New York: Plume Book.

20. Harary, C. (2002). Aggressive Play or Criminal Assault? An In Depth Look at Sports Violence and Criminal Liability. Columbia Journal of Law \& the Arts, 25, 197-217.

21. Hosta, M. (2008). Ethics and sport: whose ethics, which ethos. Kinesiology, 40(1), 89-95.

22. Ceraj, S. (2005). Šport je za osobu, a ne obrnuto. Olimp, 17, 22-25.

23. Čeh, M. (2013). Etika i sport. U V. Findak (ur.), Zbornik radova 22. ljetnje škole kineziloga Republike hrvatske - Organizacijski oblici rada u područjima edukacije, sporta, sportske rekreacije $i$ kineziterapije (str. 404-408). Poreč: Hrvatski kineziološki savez.

\title{
STRAFRECHTLICHER ASPEKT VON SPORTVERLETZUNGEN
}

\begin{abstract}
Zusammenfassung:
In dieser Arbeit wird der Begriff der Ethik im Sport definiert und darauf hingewiesen, dass Verhaltensformen existieren, die den Rahmen des Fair-Plays überschreiten. Im Rahmen der Arbeit werden ebenfalls der allgemeine Begriff der Straftat definiert, sowie Elemente des allgemeinen Begriffs der Straftat - Widerrechtlichkeit und Schuld - mit besonderer Beachtung der Grundlagen, die Widerrechlichkeit und Schuld, somit auch eine Straftat ausschließen. Besondere Aufmerksamkeit wird dem Einverständnis des Verletzten als Grundlage für die Ausschließung von Widerrechtlichkeit bei Sportwettbewerben gewidmet - mit der Betonung, dass mit seiner Zustimmung, an einem bestimmten Sport teilzunehmen, der Sportler nicht seine Zustimmung gibt, außerhalb eines für eine konkrete Sportart bestimmenden Rahmens verletzt zu werden. Es wird die Einstellung zum Ausdruck gebracht, dass der Sportler mit seiner Zustimmung die Möglichkeit akzeptiert, dass seine physische Integrität gefährdet wird, was immer noch nicht bedeutet, dass er damit einverstanden ist, wirklich verletzt zu werden, bzw. es wird ein Unterschied gemacht zwischen einer Folge, die aus einer Gefährdung besteht und einer Folge, die aus der Verletzung von Rechtsgut besteht. Die Arbeit weist auf Regeln hin, die für einzelne Sportarten gelten und in Verbindung mit dem Einverständnis des Verletzten gebracht werden. Es wird die Einstellung zum Ausdruck gebracht, dass das Einverständnis des Verletzten das Existieren einer Straftat nur dann ausschließt, wenn es zu einer Verletzung im Rahmen der Regeln einer konkreten Sportart gekommen ist. Wenn die Verletzung die Folge eines Verstoßes gegen die Sportregeln ist, handelt es sich um eine Straftat. In den Schlussbetrachtungen wird die Meinung vertreten, dass es eine Notwendigkeit ist, gegen alle schädlichen Erscheinungen im Sport anzukämpfen, somit auch gegen Verletzungen von Sportlern, die eine Folge von groben Verstößen gegen Regeln darstellen, die für einen konkreten Sport gelten. Die Schlussfolgerung weist darauf hin, dass die Zustimmung des Verletzten keine Entschuldigung für die Nichtanwendung des Strafrechts sein darf, wenn es zu einer Verletzung auf Grund von Verstößen gegen die Regeln einer Sportart gekommen ist.
\end{abstract}

Schlüsselwörter: ETHIK / FAIR-PLAY / STRAFTAT / ZUSTIMMUNG DES VERLETZTEN / AUSSCHLIEßUNG DER WIDERRECHTLICHKEIT / KÖRPERVERLETZUNG

Примљен: 10.05.2016.

Прихваћен: 02.11.2016.

(c) 2016 Autor. Objavio Fizička kultura (www.fizickakultura.com). Ovo je članak otvorenog pristupa i distribuira se u skladu sa Creative Commons licencom (http://creativecommons.org/licenses/by/3.0/rs/). 